\title{
Hvad kan en funktionel og variationistisk grammatik tilføre beskrivelsen af det franske sprog?
}

\author{
Merete Birkelund, Anita Berit Hansen, \\ Kirsten Jeppesen Kragh \& Jan Lindschouw
}

\begin{abstract}
Français)
Cet article examine trois sujets de la grammaire française : le mode, les déterminants et les prépositions qui, pour les étudiants danois, posent souvent de grands problèmes de compréhension et d'acquisition. L'examen des trois sujets se veut fonctionnel mais prend également en considération des aspects variationnistes, ceci pour illustrer nos idées de la conception d'une nouvelle grammaire française destinée aux études universitaires en français. Les aspects fonctionnel et variationniste ne représentent pas la même pertinence pour la description des trois sujets examinés, mais une description fonctionnelle qui prend en considération les variations linguistiques de la langue française contribuerait à une compréhension plus nuancée de la grammaire française.
\end{abstract}

\section{Abstract (English)}

This article examines three grammatical themes in French: mode, determiners and prepositions, often challenging the acquisition of grammatical comprehension for Danish students. The approach of the three subjects is functional, but takes also variational aspects into consideration in order to illustrate our ideas of how to conceive a new French grammar intended for university students of French. The functional and variational aspects are not equally relevant for the three examined subjects, but a functional description which takes the linguistic variations of the French language into consideration would contribute to a more balanced comprehension of the French grammar.

Nøgleord: fransk, funktionel og variationistisk grammatik, modus, determinativer, præpositioner. 


\section{Indledning}

Traditionelt har dansksprogede universitetsgrammatikker i fransk primært haft fokus på en syntaktisk tilgang til beskrivelsen af det franske sprog. Med indførelsen og konsolideringen af primært funktionelle og kommunikative tilgange til fremmedsprogsundervisningen i det danske undervisningssystem fra folkeskole over gymnasie- til universitetsniveau forekommer det os, at en syntaktisk tilgang til beskrivelsen af det franske sprog ikke længere er tilstrækkelig. Den syntaktiske beskrivelse af det franske sprog bør derfor suppleres med beskrivelser, som er baseret på funktionelle og kommunikative tilgange, hvor sprogets pragmatiske funktioner og sprogbrugernes kommunikative behov ses som udgangspunktet for de sproglige former. Dertil kommer, at en del af de dansksprogede franske grammatikker, som vi hidtil har benyttet på franskstudierne på universiteterne, ikke længere udgives : Således genoptrykkes Pedersen, Spang-Hanssen og Vikners (2000 [1980]) Fransk grammatik ikke længere. Rasmussen og Stages Moderne Fransk Grammatik udkom første gang i 1981, seneste udgave er fra 1993; den er altså mere end 30 år gammel. Nølkes Fransk grammatik og sprogproduktion, som oprindeligt var udarbejdet med henblik på franskundervisningen i gymnasieskolen, men som i en årrække har været benyttet på franskstudiet på Aarhus Universitet og også forsøgsvist på Københavns Universitet, har i modsætning til de to førnævnte grammatikker et funktionelt sprogsyn med fokus på sprogproduktion. Imidlertid er den ikke rettet direkte mod universitetsstuderende, hvorfor nogle områder ikke belyses tilstrækkeligt. Denne grammatik udgives nu kun som e-bog. Endelig er der en serie hæfter udarbejdet af Herslund et al. (1997-2004) under titlen Det franske sprog, som en del af projektet Lingvistik og fremmedsprog, igangsat af Statens Humanistiske Forskningsråd i 1993, som desværre aldrig er kommet længere end til kompendiestadiet ${ }^{1}$.

Udover at der stort set ikke længere findes nogen dansksprogede franske grammatikker til brug for universitetsstuderende, er det karakteristisk for de hidtil anvendte standardgrammatikker i fransk, at de kun i begrænset omfang tager hensyn til den variation, der præger det franske sprog. Fransk er et af de sprog, hvor der findes meget store variationistiske forskelle mellem den formelle og uformelle sprogbrug og ikke mindst mellem tale- og skriftsprog, så store, at nogle ligefrem opfatter disse variationer som en form for diglossi (Lodge 1989).

1. Materialet er dog p.t. under digitalisering og vil blive elektronisk tilgængeligt. 
Da vi så småt er i gang med at skrive en ny fransk grammatik, er det nogle af disse tanker, der har optaget os: Vi er selv rundet af den traditionelle syntaktiske måde at læse fransk grammatik på, men ser et stigende behov for at indtænke såvel funktionelle som kommunikative overvejelser og beskrivelser, ligesom vi heller ikke kan se bort fra variationistiske forskelle i fransk sprogbrug. Det betyder dog ikke, at vi i en enkelt 'standardgrammatik' kan tage højde for alle de forskelle, der findes mellem fransk talt sprog og fransk skrevet sprog. Desuden er vi bevidste om, at de studerende, vi nu modtager på de universitære franskstudier, ikke har gennemgået den samme grammatiske skoling som tidligere, en skoling, som ligger til grund for de få eksisterende dansksprogede franske grammatikker. Dette sidste er en didaktisk-pædagogisk parameter, som vi mener, er vigtig at indtænke i konciperingen af en funktionel standardgrammatik i fransk.

I denne artikel vil vi illustrere analyser af tre forskellige sprogkategorier i fransk, hvor vi vil vise, hvad vi mener en funktionel og variationistisk tilgang kan tilføre den traditionelle syntaktiske tilgang til beskrivelsen af fransk. Vi har valgt tre forskellige områder, nemlig modus, determinativer og præpositioner. Det er selvsagt alle store områder, og med den plads, vi har til rådighed, vil det være umuligt at gå i dybden og i detaljer med analysen af de tre valgte områder. Eksemplerne vil dog illustrere, i hvilken retning vi forestiller os at gå med vores udarbejdelse af en dansksproget fransk grammatik.

\section{Modus}

\subsection{Tidligere fremstillinger}

Hovedparten af de dansksprogede standardgrammatikker laver en overvejende syntaktisk gennemgang af moduskategorien. I indledningen til kapitlet om modus hævder Pedersen et al. (2000 [1980]: 319) eksempelvis, at “ [b] rugen af konjunktiv på fransk ... først og fremmest [er] styret af syntaktiske regler”. En lignende formulering finder man hos Rasmussen \& Stage (1993 [1981]: 99). De nævner, at det er "bestemte substantiver, adjektiver, verber og konjunktioner, som styrer brugen af konjunktiv". Boysen (1992: 217) opfatter ligeledes moduskategorien som overvejende syntaktisk: "I fransk følger brugen af konjunktiv og indikativ ofte faste regler".

Imidlertid gør alle disse grammatikere opmærksom på, at semantikken undertiden kan spille ind på modusvalget på fransk, navnlig i tilfælde, hvor begge modi kan forekomme efter det samme udtryk, fx i restriktive/ attributive relativsætninger (1) og (2): 
(1) Ils cherchent un mannequin qui a les cheveux roux (Pedersen et al. 2000 [1980]: 329) 'De leder efter en model, der har rødt hår'.

(2) Ils cherchent un mannequin qui ait les cheveux roux (loc.cit.) 'De leder efter en model, der har rødt hår'.

Dog gives der i grammatikkerne ikke nogen præcis forklaring på, hvilken betydningsændring modusalternationen medfører, og betydningsforskellen kommer heller ikke til udtryk i oversættelsen af eksemplerne til dansk, der er identisk i begge tilfælde. Boysen (1992: 217) nøjes med at konstatere, at "[k]onjunktivs betydning er vanskelig at bestemme generelt". Eksemplet med indikativ asserterer, at den pågældende model findes, mens eksemplet med konjunktiv ikke angiver, hvorvidt denne model findes eller ej, blot at der søges efter en model, der opfylder kriteriet om at være rødhåret.

\subsection{Problemet med de eksisterende grammatikkers frem- stilling}

Der er ikke nogen tvivl om, at modusbrugen på moderne fransk er langt mindre fri end på de øvrige romanske sprog, fx spansk og italiensk, og på tidligere sprogtrin i fransk (Lindschouw under udgivelse), hvilket til dels kan forsvare det syntaktiske udgangspunkt for de eksisterende standardgrammatikker. Imidlertid er en overvejende syntaktisk tilgang til beskrivelse af modus uhensigtsmæssig af mindst to grunde:

1. Selv i kontekster, hvor enten indikativ eller konjunktiv er den eneste mulige modus, kan man give en funktionel forklaring på, hvorfor den pågældende modus er valgt. Modusvalget skyldes således ikke sproghistoriske tilfældigheder, hvilket man kan få indtryk af, når man læser de eksisterende standardgrammatikker.

2. Det er pædagogisk uhensigtsmæssigt over for de studerende kun i begrænset omfang at inddrage semantikken/pragmatikken til beskrivelse af modus. I så fald bliver indlæring af modus reduceret til ren udenadslære for de studerende, hvilket kan virke demotiverende for dem, samtidig med at de ikke får en forståelse for, hvorfor man på fransk anvender en særegen form som konjunktiv, der kun i begrænset omfang findes på dansk.

\subsection{Funktionel/kommunikativ tilgang til modusbeskri- velsen}

Vi mener således, at der er behov for at supplere den syntaktiske tilgang til modusbeskrivelsen med en funktionel og kommunikativ tilgang, således at 
de studerende får en forståelse for, hvad man bruger indikativ og konjunktiv til i en kommunikativ sammenhæng.

I løbet af det tyvende århundrede har der været mange forskellige bud på, hvad de to modi udtrykker, nogle mere vellykkede end andre. Nogle forskere hævder, at konjunktiv udtrykker subjektivitet og indikativ objektivitet, andre at konjunktiv udtrykker tvivl og irrealis, mens indikativ udtrykker realis, andre igen at konjunktiv udtrykker noget muligt eller kontrafaktuelt, mens indikativ udtrykker noget virkeligt (se gennemgang af forskellige modusteorier i Kragh 2010: 76-87, Lindschouw 2011: 2565). Problemet med mange af disse tilgange er, at de forsøger at give en relativt snæver betydningstilskrivning til modusformerne, som kun synes at passe på nogle af forekomsterne. Eksempelvis kan man spørge sig selv, hvori tvivlskomponenten eller den irreelle komponent ligger i (3) og (4), hvor konjunktiv snarere viser sig at udtrykke noget faktuelt:

(3) Je suis content que tu ailles mieux 'Jeg er glad for, at du har det bedre'.

(4) Bien qu'il pleuve, Pierre se promène au bord de la mer 'Selvom det regner, går Pierre en tur ved havet'.

I sidste halvdel af det tyvende århundrede er der blevet fremsat en modusteori ved navn assertionsteorien. Den er oprindeligt foreslået af Hooper (1975) for spansk og siden anvendt på fransk, oprindeligt for kompletivsætninger (Korzen 1999, 2003), men siden også for adverbielle ledsætninger (Lindschouw 2002, 2011) og for relativsætninger (Mertz-Nielsen 2007, Jensen 2011).

Ifølge denne teori er indikativ den asserterende modus, dvs. den bruges til at præsentere sætningsindholdet som en ny information, som afsender selv kan stå inde for sandhedsværdien af (5). Derimod er konjunktiv den ikke-asserterende modus. Denne brede term kan forklare konjunktivs "modsatrettede" anvendelser på moderne fransk, dvs. både de kontekster, hvor den udtrykker noget faktuelt (i.e. kendt eller præsupponeret information) (3), (4), og i kontekster, hvor den udtrykker det helt modsatte, nemlig noget non-reelt, dvs. et sagforhold, der endnu ikke er realiseret på taletidspunktet eller på et referencepunkt i fortiden (6):

(5) Le directeur vient de me dire qu'il ne peut pas participer à la réunion cet après-midi 'Direktøren har lige fortalt mig, at han ikke kan komme til mødet i eftermiddag'. 
(6) Je veux que tu fasses tes leçons régulièrement 'Jeg vil have, at du laver dine lektier regelmæssigt'.

Vi mener, at dette begrebspar, asserterende/ikke-asserterende, vil kunne redegøre for hovedparten af modusanvendelser på fransk i de ledsætningstyper, hvor konjunktiv og indikativ kan forekomme, dvs. i kompletivsætninger, relativsætninger og adverbielle ledsætninger. Lad os her begrænse os til en række illustrative eksempler:

Inden for kompletivsætninger anvendes indikativ, som vi allerede har set, asserterende til at præsentere modtager for ny information, som afsender selv kan stå inde for sandhedsværdien af (jf. (5)). Konjunktiv bruges derimod ikke-asserterende til enten at præsentere kompletivsætningens indhold som præsupponeret, hvilket gælder efter følelsesudtryk og udtryk for subjektiv vurdering (jf. (3)), og som noget non-reelt, hvilket fx er tilfældet efter viljesverber (jf. (6)) og benægtede menings- og ytringsverber:

(7) Je ne crois pas que Pierre nous rende visite demain 'Jeg tror ikke, at Pierre kommer og besøger os i morgen'.

I restriktive relativsætninger kan assertionsteorien bruges til at redegøre for alternationen mellem indikativ og konjunktiv i eksempelparret (1) og (2), idet (1) med indikativ asserterer, at den pågældende model findes, mens (2) med konjunktiv ikke fortæller noget om, hvorvidt den pågældende model findes, blot at afsender leder efter en sådan. Konjunktiv udtrykker med andre ord noget non-reelt i denne kontekst.

I adverbielle ledsætninger er der meget lidt modusvariation på moderne fransk, idet de to modi er specialiseret til forskellige konjunktioner. Alligevel kan assertionsteorien også i disse kontekster forklare valget af modus. Eksempelvis kan den forklare brugen af konjunktiv i reale indrømmelsessætninger, hvor konjunktiv betegner et faktum og dermed bruges med præsupponeret værdi (jf. (4)). Den kan også forklare brugen af konjunktiv i tidsledsætninger indledt af avant que 'inden' (8) og jusqu'à ce que 'indtil' (9) og i hensigtsledsætninger indledt af fx pour que og afin que 'for at' (10). I (8) og (9) betegner konjunktiv noget non-reelt, da ledsætningsindholdet ikke er realiseret på taletidspunktet, mens konjunktiven i (10) markerer noget non-reelt i forhold til referencetidspunktet a parlé 'talte' i fortid:

(8) Rentre avant qu'il ne fasse nuit 'Kom hjem, før det bliver mørkt'.

(9) Pierre travaille jusqu'à ce que Marie soit de retour 'Pierre arbejder, indtil Marie kommer hjem'. 
(10) Paul a parlé lentement pour que/afin que tout le monde le comprenne 'Paul talte langsomt, for at alle kunne forstå ham'.

\subsection{Sprogbrugsvariation}

De netop beskrevne regler for brugen af indikativ og konjunktiv tilhører det sprogniveau, der kaldes standardfransk, dvs. det register, som beskrives i grammatikker og ordbøger, og som franske børn lærer i skolen. Imidlertid er modus et af de områder inden for den franske grammatik, hvor der findes relativt stor variation blandt sprogbrugerne, navnligt i uformelt register, især i den type, der kaldes for le français familier eller dagligdagsfransk. Vi mener, at det er vigtigt, at en standardgrammatik i fransk omtaler nogle af de væsentligste afvigelser fra standardnormen inden for modusområdet for at give de studerende et realistisk billede af modusbrugen og gøre dem bevidste om den variation, man kan observere i praksis blandt sprogbrugerne. Disse afvigelser skyldes formentlig, at indfødte franskmænd selv kan have svært ved at følge de regler, som normative og præskriptive grammatikker opstiller, og det kan samtidig forklare over for de studerende, hvorfor det kan være svært at indlære moduskategorien som fremmedsprogsstuderende. Variation inden for modus kan både gælde tilfælde, hvor normen foreskriver indikativ, men hvor mange sprogbrugere anvender konjunktiv, fx i tidsledsætninger indledt af après que 'efter at' (11). Men det vil også vedrøre det modsatte og noget hyppigere scenarie, at sprogbrugere anvender indikativ i kontekster, hvor normen foreskriver konjunktiv, eksempelvis efter benægtede menings- og ytringsverber (12) og (13), efter viljesverber (14), i restriktive relativsætninger efter non-referentielt korrelat (15) og i indrømmelsesledsætninger, fx efter konjunktionen bien que 'selvom' (16):

(11) euh ils décideront par exemple euh qu'un mot est accepté (...) après que dans le langage courant disons euh pratiquement tout le monde l'ait accepté (Elicop) 'Øhh, de vil fx beslutte, om et ord er accepteret (...), efter alle, hvad skal man sige, praktisk talt har accepteret det i daglig tale'.

(12) Je crois pas que l'âge a tant à faire avec ça (FR.003.189, cit. Poplack et al. under udgivelse: 11) 'Jeg tror ikke, at alder har noget med det at gøre'.

(13) "Je ne crois pas que les superteams sont bonnes pour la NBA" (Trashtalk 17.07.2016) 'Jeg tror ikke, at superteams er godt for basketforbundet NBA'.

(14) Fallait qu'elle répond " oui, tu peux faire trois pas de géant » (025/2186, cit. Poplack 1990: 12) 'Hun skulle bare svare «Ja, du kan tage tre kæmpe skridt »'. 
(15) il faut savoir parler à sa clientèle et une cliente qui a une idée très arrêtée sur quelque chose qui ne lui va pas (Elicop) 'Man skal vide, hvordan man skal tale til sine kunder og en kunde, der er fast besluttet på, at noget bestemt ikke passer til hende'.

(16) non je peux dire que s'il y avait des anglais ${ }^{2}$ ou s'il y avait des canadiens anglais ou des américains euh disons des anglo-saxons bien que je je sais que vous que vous faites des différences extrêmement [] euh subtiles ou importantes entre euh les les différents peuples (Elicop) 'Nej, jeg kan sige, at hvis der var englændere, eller hvis der var engelsksprogede canadiere eller amerikanere, øhh lad os sige, angelsaksere, selvom jeg godt ved, at I ikke laver en sådan subtil eller vigtig skelnen mellem forskellige befolkningsgrupper'.

\section{Determinativer}

Fransk er karakteristisk ved en meget stringent og konsekvent anvendelse af determinativer, og området volder ofte danske franskstuderende en del problemer, ikke mindst anvendelsen af den såkaldte delingsartikel, men også generelt i deres forståelse af den franske determinativsyntaks. Disse vanskeligheder skyldes bl.a., at der tages udgangspunkt i dansk, hvor vi fx finder valg mellem $\varnothing$-form og nogle i ubestemt pluralis,

(18) Det var nogle dyre biler (Hansen \& Heltoft 2011: 179)

Her angiver $\varnothing$-formen biler som værende medlemmer af en kategori, samtidig med at de ikke er individualiserede, mens nogle peger på enkelte eksemplarer af gruppen. På fransk benytter man derimod artikel i pluralis i begge tilfælde:

(19) Il aimait les voitures chères 'Han elskede dyre biler'.

I eksempel (19) er der tale om den generiske artikel, som er en særlig anvendelse af den bestemte artikel, mens der i eksempel (20) er tale om den ubestemte artikel i pluralis:

2. Nationalitetssubstantiver skrives normalt med stort begyndelsesbogstav på fransk. Her henholder vi os til Elicops officielle transskription. 
(20) C'était des voitures chères 'Det var nogen dyre biler.'

Ø-formen findes kun i særlige tilfælde, idet determinativer på fransk er nødvendige for at etablere reference, hvilket gælder såvel i singularis som i pluralis, både i ubestemt og i bestemt form.

\subsection{Standardgrammatikkernes beskrivelse af determina- tivernes form og funktion}

Der er i standardgrammatikkerne for fransk ikke nogen større uoverensstemmelser med hensyn til, hvad der opfattes som artikler, og hvilken funktion de udfylder, idet en artikel defineres som det ord, der er placeret foran et substantiv. Artikel og substantiv udgør et substantivsyntagme på konstituentniveau. På funktionsniveau er der tale om et nominalsyntagme bestående af determinativ + kerne. Følgende ordklasser kan optræde som determinativ:

Bestemte determinativer:

Bestemt artikel: le, la, les

Demonstrativer: $\mathrm{ce}$, cette, ces

Possessiver: mon, ton, son, ...

Ubestemte determinativer:

Ubestemt artikel: un, une, des

Partitiv artikel (delingsartikel): $d u$, de la, des

Indefinitte pronominer (artikler): certain, tout, chaque, quelque(s), plusieurs Nægtende indefinitte pronominer (artikler) aucun, nul, pas un, ... ${ }^{3}$

Interrogativer: quel, lequel

\subsection{Tidligere fremstillinger af delingsartiklen vs den ubestemte artikel}

Fokus i det følgende vil være på den ubestemte artikel og den partitive artikel (delingsartiklen), hvis anvendelse ofte volder danske franskstuderende problemer at indlære. Traditionelt opstiller standardgrammatikkerne en række regler for delingsartiklens anvendelse på fransk og opfatter den nærmest som en ekstra ubestemt artikel.

Standardgrammatikkerne anfører, at valget af artikel afhænger af substantivets semantiske indhold, dvs. konkret/abstrakt og tælleligt/utælleligt. Dog siger Rasmussen \& Stage, at den "i ental [udtrykker] en ubestemt mængde

3. Disse kan også have en pronominel funktion, hvilket vi ser bort fra i denne sammenhæng. 
af noget, der ikke kan tælles; i flertal et ubestemt antal af noget, der kan tælles. (...) Delingsartiklen forekommer ved både konkrete og abstrakte substantiver" (1993 [1981]: 152-153), og de giver følgende eksempler, men forklarer ikke anvendelsen yderligere:

(21) Je voudrais du chewing-gum, du chocolat et des pastilles de menthe. (Rasmussen \& Stage 1993 [1981]: 153) 'Jeg vil gerne have noget tyggegummi, noget chokolade og nogle pebermyntepastiller'.

(22) Vous avez de la chance. (Rasmussen \& Stage 1993 [1981]: 153) 'De er heldig'.

(23) Avez-vous des chambres libres? (Rasmussen \& Stage 1993 [1981]: 153) 'Har De nogle ledige værelser?'

Den ubestemte artikel "anvendes til at introducere ikke tidligere omtalte størrelser i teksten” (Pedersen et al. 2000 [1980]: 140), eller stort set som på dansk. "Den udtrykker det ikke nærmere bekendte, i ental et enkelt eksemplar, i flertal et ubestemt antal" (Rasmussen \& Stage 1993 [1981]: 155). Videre siges det hos Rasmussen og Stage, at "[f]ormen i ental er lig med talordet 'én'. Formen i flertal er lig med delingsartiklen" (1993 [1981]: 155). Nærmere forklaring gives ikke, men kan nok bruges som 'udenadslære', selvom det måske synes mere beskrivende end egentligt forklarende. For at give franskstuderende mere end blot en række regler for brugen af den ubestemte og partitive artikel har vi ladet os inspirere bl.a. af Riegel et al.'s Grammaire méthodique du français (2009 [1994]) og Herslund (1997) Fransk som klassifikatorsprog, hvis udgangspunkt er at opfatte de franske ubestemte artikler som en slags klassifikatorer.

Ifølge standardgrammatikkerne er brugen af de ubestemte artikler på fransk tæt relateret til den semantiske kategori, som substantivet tilhører, dvs. om substantivet tilhører gruppen af konkrete eller abstrakte substantiver, og om der er tale om tællelige eller utællelige substantiver.

\subsection{En funktionel/kommunikativ tilgang til beskrivelsen af delingsartiklen og den ubestemte artikel}

I modsætning til hvad man kunne forledes til at tro ifølge standardgrammatikkerne, fordeles artiklerne imidlertid ikke automatisk, således at tællelige, heterogene substantiver kombineres med den ubestemte artikel un og utællelige, homogene substantiver med delingsartiklen $d u$ eller de la. Artiklens funktion er at markere substantivsyntagmet med hensyn til +/-homogenitet: delingsartiklen anvendes til at udtrykke +homogenitet: $d u$ vin (dvs. 'vin' 
som masse) og den ubestemte artikel til at udtrykke -homogenitet: un vin (dvs. 'vin' som type). Alle substantiver kan således i princippet kombineres med begge artikler, men valget afgøres af det indhold, substantivet i den pågældende kontekst skal tillægges. Fransk skelner således ikke leksikalsk mellem tællelige og utællelige substantiver, men substantiverne har derimod brug for en ekstern betydningskomponent for overhovedet at kunne angive den relevante denotation (jf. Herslund 1997: 39). For at skabe et ubestemt substantivsyntagme bliver et ubestemt determinativ på fransk dermed altid nødvendigt, hvad enten det er den ubestemte artikel un, som tilfører substantivet status af en enhed, eller delingsartiklen $d u$, som tilfører substantivet status af substans eller masse. Da alle franske substantiver kan kombineres med begge artikler, afgør valget mellem den ubestemte artikel og den partitive artikel det indhold, substantivet i den pågældende kontekst skal tillægges.

Det franske substantivs status skal altså markeres ved en artikel og kan ikke udelades, netop fordi den er nødvendig for en fastlæggelse af substantivsyntagmets værdi.

Hvis vi kan introducere en sådan beskrivelse, vil det forhåbentligt give vores studerende en bedre forståelse af brugen af de ubestemte determinativer på fransk, og det vil formodentligt blive nemmere at forklare, hvilke betydningsforskelle der kan opstå - afhængig af den givne kontekst i et syntagme som du lion - 'løve' (= begrebet), 'løvekød' (= masse), 'løveagtigt' (begrebets intension) - og også at syntagmet un lion kan have to betydninger, enten 'en løve' forstået som en enhed eller i betydningen 'type'.

Følger man Herslunds tanke om at regne fransk som et klassifikatorsprog, kan klassifikatorer på fransk inddeles i to grupper: "de simple, som indgår i determinativsystemet, og de komplekse, som består af leksikalske elementer, med en høj grad af subjektiv og kreativ udnyttelse" (Herslund 1997: 54).

Eksempler på simple klassifikatorer:

un $=$ heterogen

$d u=$ homogen

Eksempler på komplekse klassifikatorer:

Un kilo de pommes 'Et kilo æbler'

Un litre de vin 'En liter vin'

Un morceau de sucre 'Et stykke sukker' 


\subsection{Komplekse klassifikatorer og den reducerede delings- artikel}

Traditionelt forklarer standardgrammatikkerne, at ubestemte substantivsyntagmer der står som objekt for et benægtet verbum, ikke indledes af en delingsartikel eller en ubestemt artikel, men derimod erstattes af den reducerede delingsartikel $d e$ :

(24) Il n'a pas d'enfants 'Han har ikke nogen børn.'

Den reducerede delingsartikel de forveksles ofte af den sprogstuderende med præpositionen $d e$, som findes i kombination med en række substantiviske udtryk, der angiver mængde eller kvantitet, $\mathrm{x}$ un kilo de, un paquet de, une boîte de, un litre de, un grand nombre de, une centaine de, etc., eller adverbielle udtryk for mængde som fx beaucoup de, combien de, plus de, moins de, un peu de, trop de, tant de, etc., men præpositionen de kan ikke kombineres med en delingsartikel, og der sker ifølge den traditionelle analyse et bortfald af delingsartiklen, således at vi får fx:

(25) Il y a beaucoup de bouteilles de vin dans la cave 'Der er mange flasker [med/af] vin i kælderen.

(26) Je voudrais un kilo de pommes 'Jeg vil gerne have et kilo [af] æbler.

Umiddelbart er der tale om en regel, som nok kan indlæres, men den syntaktiske forklaring af dette fænomen kunne man af pædagogiske grunde foreslå at analysere således, at mængdeudtrykket (beaucoup de, o.l.) opfattes som ét samlet determinativ. I henhold til en sådan analyse ville beaucoup de, un kilo de fungere som et komplekst (kreativt) determinativ og ikke som den referentielle kerne. Sådanne 'kreative' determinativer forstås nok bedst i en grammatikaliseringsoptik, forstået således at de ord, der indgår i den grammatikaliserede struktur (mængdeudtrykket) ' _ + de', har mistet noget af deres leksikalske betydning, således fx

$$
\text { J'ai bu trois tasses de thé 'Jeg har drukket tre kopper [af] te.' }
$$

hvor trois tasses fungerer som en mængdeangivelse. Det er ikke kopperne som sådan, afsender refererer til, men snarere teen (jf. Jønsson 2011). En sådan analyse præsenteres ikke i standardgrammatikkerne, men den kunne evt. facilitere de studerendes tilgang til forståelsen af reduktion og/eller bortfald af delingsartiklen. 


\subsection{Variationistiske overvejelser}

Som nævnt foreskriver normen et determinativ som indleder af et nominalsyntagme på fransk. Dette er imidlertid ikke altid tilfældet i talt sprog, idet man her finder eksempler, hvor determinativet enten ikke er til stede, sådan som standardsproget kræver det:

Ø logement, c'est important (cit. Gadet 1992: 60) 'Lejlighed, det er vigtigt'.

eller hvor franskmænd anvender en fuld delingsartikel, mens normen foreskriver reduktion af den:

(29) elle avait pas assez de l'eau (cit. Gadet 1992: 60) 'Hun havde ikke nok [af noget] vand'.

\section{Præpositioner}

Korrekt brug af præposition er et af de sværeste emner i fremmedsprogsindlæring, og selv på meget tæt beslægtede sprog kan der være store forskelle, når det gælder brug af præpositioner. Det er således ofte i anvendelsen af præpositioner, at selv meget stærke L2 sprogbrugere falder i og afslører sig som ikke-modersmålstalende. Det hænger formentlig sammen med, at hver præposition kan indgå i en lang række alternationer med andre præpositioner og således kan udtrykke en række betydningsnuancer, som kan være svære at opfange og mestre for fremmedsprogsbrugeren. Ikke desto mindre er der ikke nogen tradition for, at behandlingen af præpositioner har nogen særlig stærk position i grammatikundervisningen, og da slet ikke med nogen særligt anvendelsesorienteret tilgang.

\subsection{Tidligere fremstillinger}

Traditionelt set arbejdes der i grammatikundervisningen primært med præpositioner i de indledende forløb, hvor sætningsanalysen er i centrum, dvs. at undervisningen fortrinsvist tager udgangspunkt i præpositionssyntagmets opbygning. Senere kan der arbejdes med præpositionernes syntaks og deres inddeling efter semantiske principper.

I de fleste dansksprogede standardgrammatikker beskrives præpositionernes syntaktiske forhold, dvs. syntagmets opbygning, adskilt fra både form (sammensat/usammensat) og funktion.

Hos Pedersen et al. (2000 [1980]: 14-15) præsenteres præpositionssyntagmer således i det indledende kapitel om 'elementære strukturer', hvor beskrivelsen primært drejer sig om, at syntagmet principielt er toleddet, dvs. 
består af et præpositional og en styrelse. Derudover drejer et helt kapitel sig om præpositioner, og dette beskriver dels en række generelle træk ved det franske præpositionssystem, dels en række mere eller mindre tilfældige særanvendelser med hhv. semantiske og syntaktiske tilgange. Endelig præsenteres usammensatte præpositioner over for sammensatte. De generelle træk tager igen udgangspunkt i en række meget heterogene aspekter, fx betydningsfattige eller betydningsrige præpositioner (semantik), skel mellem attributive og adverbielle præpositionssyntagmer (syntaks), retningsangivelse ved hjælp af præpositioner (semantik) (Pedersen et al. 2000 [1980]: 438-442).

Rasmussen \& Stage (1993 [1981]: 284-314) har en noget mere overskuelig gennemgang, hvor der introduceres med den syntaktiske beskrivelse af præpositionssyntagmet, men også her virker blandingen af semantik og syntaks lidt forvirrende, selvom der er en noget større grad af kommunikativ orientering i kapitlet. Et gennemgående træk er den kontrastive semantiske dimension, idet der lægges stor vægt på at illustrere den danske pendant til en given form.

I Nølke (1997) er der igen en opdeling mellem syntaks og form, men her er der suppleret med en - ganske vist overfladisk - opremsning af præpositionernes semantik.

\subsection{Funktionel/kommunikativ tilgang til beskrivelsen af prapositioner}

$\mathrm{Vi}$ vil gerne præsentere en tilgang til emnet, der forener de syntaktiske forhold og de semantiske og morfologiske dimensioner med det mere anvendelsesorienterede perspektiv. Vi er blevet inspireret af Helland (2006), der til trods for sin relativt generative tilgang har samlet de forskellige perspektiver på en måde, der faktisk lægger op til en mere funktionel og anvendelsesorienteret tilgang, nemlig ved at integrere det kommunikative og semantiske aspekt i den syntaktiske tilgang.

Vi betragter ordklassen præpositioner som en form for hybrid ordklasse, der har træk tilfælles med både åbne og lukkede ordklasser. Som de lukkede ordklasser kan de have rene grammatiske funktioner, fx når de angiver genitiv:

(30) La grammaire de la langue française 'det franske sprogs grammatik'. (31) La construction de la ville 'byens opbygning'.

Her har de ikke noget specifikt semantisk indhold, men fungerer udelukkende som grammatisk markør, der kan angive fx ejerforhold (30) og ob- 
jektiv genitiv (31). Selvom præpositionen fungerer som grammatisk markør, har den alligevel en form for betydningsbærende dimension i konteksten, hvilket understreges af, at det ikke er ligegyldigt, hvilken præposition der anvendes. I andre tilfælde bevarer præpositionen semantisk indhold, fx når den udtrykker hensigt eller mål:

$$
\text { Il sort pour aller au travail 'Han går ud for at gå på arbejde'. }
$$

Vi vil i det følgende se på inventaret af former, hvordan præpositionen optræder som præpositional i sit syntagme og går i solidaritetsforbindelse med sin styrelse, præpositionssyntagmets syntaktiske funktioner og endelig på en mulig opdeling af præpositionerne i syntaktisk og semantisk funktion.

\subsubsection{Enkle og sammensatte prapositioner}

De enkle former udgør en lukket ordklasse og kan opdeles i hovedgrupper efter semantiske træk, fx:

Stedsbetydning: $\grave{a}\left(=\mathrm{i}\right.$, på, til, etc.); de (=fra); chez (=hos); dans $(=\mathrm{i})$; devant ${ }^{4}$ (=foran); derrière (=bag(ved)); en $(=\mathrm{i})$; entre (=mellem); sur (=på); sous (=under); vers (=til, mod); contre (=mod)

Tidsbetydning: $\grave{a}$ (=til, i, på); après (=efter); avant (=inden); de (=fra); dans (=om); depuis (=siden, $\mathrm{i})$; en ( $=\mathrm{i} / \mathrm{på})$; entre (=mellem); pendant (=under); vers $(=\bmod )$

Andre betydninger: avec (=med); contre (=imod); pour (=for); sans (=uden); $\operatorname{par}(=\mathrm{ad})$

Bemærk, at nogle af formerne optræder i flere grupper, dvs. de har flere betydninger.

De sammensatte former kan på sin vis betragtes som en form for en produktiv klasse, hvilket vil sige, at der stadig kan opstå nye former med specialiserede betydninger. Disse er sværere at inddele, da der kan være tvivl om afgrænsningen af dem, dvs. om der reelt er tale om en sammensat præposition eller snarere om en fri form af en ordgruppe:

$$
\begin{aligned}
& \text {... à cause de son anniversaire (på grund af hans fødselsdag) } \\
& \text {... à l'occasion de son anniversaire (i anledning af hans fødselsdag) }
\end{aligned}
$$

4. En række af disse er historisk set sammensatte, fx devant, depuis, après, malgré, etc. men de er grammatikaliserede og opfattes i moderne fransk som enkle former. 
Mens à cause de (33) traditionelt set behandles som en sammensat præposition, er definitionen af à l'occasion de (34) som en sammensat præposition mindre entydig, og denne kunne derfor måske opfattes som et nyere medlem af ordklassen. For at komme denne usikkerhed til livs, vil vi behandle begge eksempler som sammensat præposition ud fra følgende kriterier:

- Hovedparten af sammensatte præpositioner har ikke determinativ foran substantivet ( $\mathrm{fx}$ cause i à cause de). Hvis der optræder determinativ, vil det ikke kunne erstattes med andre determinativer (fx $\grave{a}$ l'occasion de, men ikke *à une occasion de eller *à cette occasion de $\left.e^{5}\right)$.

- Der kan ikke knyttes en modifikator til substantivet ( $\mathrm{fx} * a ̀$ mauvaise cause de)

Det første kriterium gælder for begge eksempler, men det sidste kriterium gælder kun for à cause de, da man strengt taget godt kan sige à l'occasion solonelle de, hvilket understreger, at à l'occasion de er mindre entydig som sammensat præposition.

I alt 300-400 konstruktioner anerkendes i grammatiske beskrivelser som sammensatte præpositioner i moderne fransk (Helland 2006: 198).

\subsubsection{Prepositionssyntagmets indre struktur}

Præpositioner kan normalt ikke stå alene, men optræder sammen med en størrelse, styrelsen. Præpositionalet og styrelsen udgør tilsammen et præpositionssyntagme, som vi kalder en solidaritetsforbindelse eller neksusforbindelse, fordi begge led er ligeværdige, dvs. man kan ikke udelade nogen af delene, uden at sætningen bliver ugrammatisk:

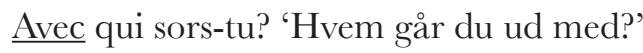

På dansk kan man sagtens finde Jeg kommer med eller Jeg legger på nu, men dette er ikke muligt på fransk, hvor præpositionen skal følges af en styrelse: fe viens avec toi. Kun i fă tilfælde kan styrelsen være implicit, hvis den kan udledes af konteksten:

(36) Est-il pour ou contre? 'Er han for eller imod?'

5. Bemærk at man godt kan have à cette occasion. Men der er ikke tale om sammensat præposition, idet vi blot har præpositionen $\grave{a}$ og styrelsen cette occasion. 


\subsubsection{Prepositionssyntagmets syntaktiske funktioner}

Præpositionssyntagmet kan optræde i en lang række syntaktiske funktioner, både på sætningsniveau og på syntagmeniveau. På sætningsniveau står det som adverbial:

(37) Il a vécu vingt ans avec ses parents. 'Han har levet 20 år med sine forældre'.

(38) Il est allé à Paris. 'Han er taget til Paris'.

som indirekte objekt:

(39) Le ministre parle d'un problème national. 'Ministeren taler om et nationalt problem'.

som dativobjekt:

(40) Il a donné des fleurs à sa mère. 'Han har givet blomster til sin mor'. som subjektsprædikat:

(41) Elle est toujours de bonne humeur. 'Hun er altid i godt humør'.

På syntagmeniveau står præpositionssyntagmerne typisk som attributiv til kernen i et substantivsyntagme:

(42) C'est un garçon de 10 ans. 'Han er en 10-årig dreng'.

som underled i et adjektivsyntagme:

(43) Elle est sensible au froid. 'Hun er følsom over for kulde'.

eller som underled i et adverbiumsyntagme:

(44) Il agit toujours conformément aux règles 'Han handler altid i overensstemmelse med reglerne'.

4.2.4. Klassificering af prepositionerne $i$ relation til syntaktisk og semantisk funktion

De usammensatte præpositioner kan inddeles i betydningsfattige og betydningsrige præpositioner. Præpositionerne de, à og en har i de fleste forbindelser en vag, abstrakt betydning og har alene den funktion at etablere en 
sammenhæng mellem ord, hvor de "représente un maximum d'abstraction" (Spang-Hanssen 1963: 12). Denne rolle er særlig udpræget, når de fx indleder et indirekte objekt (jf. eksempel (39) ovenfor) eller et attributivt led:

(45) La voiture de Pierre 'Pierres bil'.

Eller når à sammen med styrelsen angiver et sted:

(46) Il est à la maison. 'Han er hjemme'.

De øvrige præpositioner har for de flestes vedkommende en fyldigere form og i almindelighed en mere præciserende og konkret betydning - tunge betydningsrige præpositioner.

(47) Il est dans la maison. 'Han er inde i huset'.

I mange tilfælde kan der varieres mellem betydningsfattig (let, abstrakt) og betydningsrig (tung, konkret) præposition. De lette præpositioner de, à og en danner en tættere forbindelse med styrelsen end de tungere præpositioner. Hvis forbindelsen mellem præposition og styrelse løsnes, er der en tendens til at anvende en tungere præposition. Således kan den betydningsrige præposition fremkaldes af en række syntaktiske faktorer, fx artikelvalg (48) eller tilstedeværelse af attributiv (49):

(48) Nous allons dîner dans ce restaurant (Nous allons diner au restaurant) 'Vi skal spise på denne restaurant (Vi skal spise på restaurant)'.

(49) La brochure est écrite dans un français élégant (La brochure est écrite en français) 'Brochuren er skrevet på et elegant fransk (Brochuren er skrevet på fransk)'.

\subsection{Variationistiske overvejelser}

Brugen af præpositioner er ikke et område, der typisk er genstand for variationistiske betragtninger. Enkelte tegn ser vi i uformel sprogbrug, hvor man undertiden udelader styrelsen (jf. Guiraud 1978 [1965]: 73-76):

(50) Il est parti avec 'Han er taget af sted med'.

(51) Tu es avec? 'Er du med?' 
Ellers ses udeladelse af styrelse stort set kun i det faste udtryk être pour ou contre 'være for eller imod'.

\section{Konklusion}

De tre gennemgåede emner - modus, determinativer og præpositioner er alle vanskelige for dansksprogede franskstuderende. Ved at fremhæve funktionelle og variationistiske elementer i den grammatiske fremstilling er det vores håb at nuancere og optimere indlæringen samtidig med, at vi gør de studerende mere opmærksomme på variationsænomener i hverdagssproglig fransk syntaks. Som det vil være fremgået, er de funktionelle og variationistiske aspekter dog ikke lige fremtrædende for alle tre emner (og vil være det i varierende grad for de øvrige emner, en ny universitetsgrammatik måtte indeholde).

Opsamlende kan man sige, at det funktionelle dog synes at kunne gives en eller anden plads ved alle de behandlede emner. For modusbrug på fransk kan der oplagt tilføjes relevante nye funktionelle vinkler, takket være assertionsteorien, idet konjunktiv kan forbindes med ikke-asserterende betydning og indikativ med asserterende betydning. Dermed behøver modus ikke udelukkende at blive indlært som et komplekst syntaktisk styret fænomen, selvom syntaktiske regler også vil være nødvendige i et vist omfang. For determinativbrug kan man ligeledes gøre de studerende mere følsomme over for betydningskomponenten ved $\mathrm{fx}$ at introducere til, at delingsartiklen i ental ikke slavisk placeres foran "noget der ikke kan tælles" (jf. du vin = 'vin'), men faktisk aktivt kan bruges til at fremkalde en bestemt mening foran et hvilket som helst substantiv, som man ønsker opfattet som en homogen masse ( $\mathrm{fx} d u$ lion $=$ 'noget løvekød'). Men det er klart, at der derudover vil være en hel del inventar over artikeltyper og andre determinativkonstituenter og deres respektive brug, der næppe kan præsenteres meget anderledes end i standardgrammatikker. Endelig kan man i forhold til præpositionsbrug på fransk gøre studerende mindre rådvilde over for valg af præposition ved at understrege, at fx 'på' findes i en betydningsmæssigt afbleget/abstrakt udgave i faste udtryk og generelle vendinger (à: Nous allons dîner au restaurant $=$ 'Vi skal spise på restaurant' $/$ 'Vi skal ud og spise') og i en betydningsmæssig mere konkret udgave i mere individualiserede udtryk (dans: Nous allons dîner dans ce restaurant $=$ 'Vi skal spise på denne restaurant' [frem for en anden]). Også her vil en del af indlæringen dog nødvendigvis skulle omhandle det obligatoriske partnerskab mellem præposition og styrelse på standardfransk samt inventaret af enkle og sammensatte præpositioner. 
Det variationistiske synes sværere at anvende som et konsekvent aspekt i fremstillingen af de tre udvalgte emner af den simple grund, at ikke alle franske syntakselementer er involverede i situationsbetinget formvariation. Der er rige observationer af modusvariation (jf. eksemplerne på, at uformelt fransk varierer mellem indikativ og konjunktiv i kontekster, hvor standardreglerne - og asserteringsværdien - peger på enten den ene eller den anden modus (après que + indikativ eller konjunktiv, trods indikativ i standardfransk (asserterende), je ne crois pas que + indikativ eller konjunktiv, trods konjunktiv i standardfransk (ikke-asserterende)). Men det er langt sværere at finde dokumenterede observationer af en særlig uformel sprogbrug inden for determinativer og præpositioner (jf. at vi i gennemgangen stort set kun har kunnet nævne muligt drop af artikel (jf. Ølogement, c'est important) og drop af styrelse (jf. Il est parti avec Ø.) og kun har kunnet trække på fragmentariske bemærkninger i Guiraud (1978 [1965]) og Gadet (1992). Vi har med andre ord ikke kunnet understøtte disse betragtninger med empiriske variationistiske studier som ved modusvariationen. Sandsynligvis skyldes denne forskel, at syntaktiske enheder som determinativer og præpositioner har en mere grammatisk funktion og udgør mere lukkede sæt af enheder og derfor ikke udgør et potentiale, der i samme grad appellerer til sprogbrugerens udnyttelse.

I det videre arbejde med de variationistiske aspekter i grammatikken må vi også forholde os til, at der især i 1980'erne og 1990'erne fandt en følelsesladet diskussion sted vedrørende anvendelsen af det variationistiske paradigme inden for syntaks (jf. Lavandera 1978, Romaine 1984, Milroy 1987, Sankoff 1988, Goveney 1996, Winford 1996, Gadet 1997)6. Det var især spørgsmålet om semantisk ækvivalens mellem de varierende former, der delte vandene. Der findes i dag derfor overvejende variationistiske syntaksstudier for de fænomener, hvor der opstod konsensus om, at ækvivalensspørgsmålet ikke var et større problem. Disse fænomener er for fransks vedkommende fx følgende, hvor den mest formelle form står til venstre:

- Nægtelser

Il ne vient pas / Il vient pas (cf. Coveney 1996, Hansen \& Malderez 2004) 'Han kommer ikke'

- Spørgekonstruktioner

Viens-tu?/Est-ce que tu viens ?/Tu viens? (Coveney 1996, Hansen 2001) 'Kommer du?'

6. Se opsamling i Hansen (1999) og Hansen (2004) 


\section{- Pronominer}

Nous sommes 19 dans ma classe / On est 19 dans ma classe (Coveney 2000, Hansen 2013) 'Vi er 19 i min klasse'.

For ovenstående emner, ligesom for modus, vil det at inddrage den stilistiske variation mellem former være en nyttig - og forhåbentlig teoretisk set uproblematisk - ekstraoplysning for de studerende.

Kombinationen af både at ville give nogle funktionelle og nogle variationistiske tillægsaspekter til de syntaktiske emner er dog desværre ikke helt uproblematisk i sig selv. Vi er klar over det potentielt selvmodsigende i først at insistere på, at en bestemt form har en bestemt betydning - fx i tilfældet med konjunktiv og den ikke-asserterende værdi - og bagefter anføre, at franske modersmålstalende i et vist omfang ignorerer denne betydning $\mathrm{fx}$ ved at de i kontekster, der burde have en bestemt modusbrug, bruger indikativ og konjunktiv i flæng. ${ }^{7}$ Sammenstødet mellem det at anerkende, at hver form har sin betydning, og det, at sprogbrugerne i nogen tilfælde synes at være ret frie i deres brug af formerne og måske endda i en særlig kontekst er ved at forlade en form, som grammatikker og lingvister har forsvaret og forklaret den særlige betydning af gennem mange år, er i hvert fald et aspekt, vi i grammatikken bliver nødt til at adressere for ikke at virke usammenhængende.

\section{Henvisninger}

Boysen, G. (1992). Fransk grammatik. København: Munksgaard.

Coveney, A. (1996). Variability in spoken French. A sociolinguistic study of interrogation and negation. Exeter: Elm Bank Publications.

Coveney, A. (2000). Vestiges of nous and the 1st person plural verb in informal spoken French. Language Sciences 22, 447-481.

Fleischman, S. (1982). The future in thought and language. Diachronic evidence from Romance. Cambridge: Cambridge University Press.

7. Et helt parallelt tilfælde har man på fransk med fremtidsformerne morfologisk og perifrastisk futurum: je chanterai/je vais chanter, hvor en funktionel tilgang vil fremhæve den særlige distinkte betydning af de to former, mens variationistiske studier viser, at sprogbrugerne anvender begge former i samme kontekst, og at der i et vist omfang snarere er tale om formalitetsbestemt variation: "[J]e vais chanter in conversation has taken over for the most part the temporal function of [je] chanterai..." (Fleischman (1982: 99), citeret af Helland (1995: 21). Se endvidere fremstilling i Hansen \& Strudsholm (2006: 191-193). 
Gadet, F. (1992). Le français populaire. Paris: Presses Universitaires de France. Gadet, F. (1997). La variation en syntaxe. Paris: Larousse.

Guiraud, P. (1978 [1965]). Le français populare (4e ed. Vol. 1172). Paris: Presses Universitaires de France.

Hansen, A.B. (1999). Traitement variationniste des problèmes syntaxiques exemples du français parlé. I: La langue, les signes et les êtres: Actes du colloque de l'Institut d'Etudes Romanes de l'Université de Copenhague, le 3 octobre 1998 44. Lund, H.P. (red.). København: Museum Tusculanum Press, 29-46.

Hansen, A.B. (2004). Approche tridimensionnelle de la variation diaphasique en français - étude pilote. I: Sept approches à un corpus. Analyses du français parlé. Andersen, H.L. \& C. Thomsen (red.). Bern/Berlin/Bruxelles/ Frankfurt-am-Main/New York/Oxford/Wien: Peter Lang, 107-137.

Hansen, A.B. (2013). Diaphasic variation and change in French pronouns. Different uses of on with special reference to the on/nous alternation. I: Deixis and Pronouns in Romance Languages. Kragh, K.J. \& J. Lindschouw (red.). Amsterdam/Philadelphia:John Benjamins Publishing Company, 125-143.

Hansen, A.B. \& I. Malderez (2004). Le NE de négation en région parisienne : une étude en temps réel. Langage et société 107 (mars 2004), 5-30.

Hansen, A.B. \& E. Strudsholm (2006). Morphological and periphrastic future in French and Italian spoken language : Parellel tendencies? I: La linguistique au cœur. Valence verbale, grammaticalisation et corpus. Mélanges offerts à Lene Schøsler à l'occasion de son 60e anniversaire. Andersen, H.L., M. Birkelund \& M.-B. Mosegaard Hansen (red.). Odense: University Press of Southern Denmark, 189-218.

Hansen, E. \& L. Heltoft (2011). Grammatik over det danske sprog (Vol. 1). København: Det Danske Sprog- og Litteraturselskab.

Hansen, M.-B.M. (2001). Form and function of yes/no interrogatives in spoken Standard French. Studies in Language 25 (3), 463-512.

Helland, H.P. (1995). Futur simple et futur périphrastique : du sens aux emplois. Revue Romane 30, 3-26.

Helland, H.P. (2006). Ny fransk grammatikk. Morfologi, syntaks og semantik. Oslo: Universitetsforlaget.

Herslund, M. (1997). Fransk som klassifikatorsprog. I: Ny Forskning i Grammatik 5. Colliander, P. \& I. Korzen (red.). Odense: Odense Universitetsforlag, 37-56.

Herslund, M., H. Korzen, H. Nølke \& F. Sørensen (1997-2004). Det franske sprog. Handelshøjskolen i København.

Hooper, J.B. (1975). On assertive predicates. Syntax and Semantics 4, 91-124. 
Jensen, T.O. (2011). La théorie de l'assertion et le subjonctif dans les propositions relatives restrictives en français moderne. Københavns Universitet, upubliceret bachelorprojekt.

Jønsson, M. (2011). Grammaire nominale et la complétive adnominale. Aarhus Universitet, upubliceret ph.d.-afhandling.

Korzen, H. (1999). Principper for opstilling af modus i kompletivsætninger på fransk. I: Ny forskning i grammatik 6. Bache, C., L. Heltoft \& M. Herslund (red.). Odense: Odense Universitetsforlag, 181-203.

Korzen, H. (2003). Subjonctif, indicatif et assertion ou : Comment expliquer le mode dans les subordonnées complétives? I: Aspects de la modalité. Birkelund, M., G. Boysen \& P.S. Kjærsgaard (red.). Tübingen: Max Niemeyer Verlag, 113-129.

Kragh, K.J. (2010). Le remplacement de l'imparfait du subjonctif par le présent du subjonctif considéré dans une perspective de grammaticalisation. Copenhagen: Museum Tusculanum Press.

Lavandera, B. (1978). Where does the sociolinguistic variable stop? Language in Society 7, 171-182.

Lindschouw, J. (2002). Konjunktiv på fransk og spansk, et spørgsmål om assertion? Undersøgelse af en konjunktivteori appliceret på franske og spanske adverbielle ledsatninger. Københavns Universitet, upubliceret specialeafhandling.

Lindschouw, J. (2011). Etude des modes dans le système concessif en français du 16e au 20 e siècle et en espagnol moderne. Copenhagen: Museum Tusculanum Press.

Lindschouw, J. (under udgivelse). Tense, aspect, and mood. I: Manual of Romance Morphosyntax and Syntax. Dufter, A. \& E. Stark (red.). Berlin: Mouton de Gruyter.

Lodge, A. (1989). Speakers' perceptions of non-standard vocabulary in French. Zeitschrift für romanische Philologie 105 (5-6), 427-444.

Mertz-Nielsen, S. (2007). L'emploi de mode dans une proposition relative avec un superlatif ou une expression superlative dans l'antécédent. Københavns Universitet, upubliceret bachelorprojekt.

Milroy, L. (1987). Observing and Analysing Natural Language. Oxford: Basil Blackwell.

Nølke, H. (1997). Fransk grammatik og sprogproduktion. København: Kaleidoscope.

Pedersen, J., E. Spang-Hanssen \& C. Vikner (2000 [1980]). Fransk Grammatik (1. udgave, 9. oplag ed.). København: Akademisk Forlag.

Poplack, S. (1990). Prescription, intuition et usage: Le subjonctif français et la variabilité inhérente. Langage et société 54, 5-33.

Poplack, S., R. Torres Caucollos, N. Dion, R. de Andrade Berlinck, S. 
Digesto, D. Lacasse \& J. Steuck (under udgivelse). Variation and grammaticalization in Romance: A cross-linguistic study of the subjunctive. I: Manuals in Linguistics: Romance Sociolinguistics. Ayres-Bennett, W. \& J. Carruthers (red.). Berlin: Mouton de Gruyter.

Rasmussen, J. \& L. Stage (1993 [1981]). Moderne Fransk Grammatik. København: Det Schønbergske Forlag.

Riegel, M., J.-C. Pellat \& R. Rioul (2009 [1994]). Grammaire méthodique du français (5 ed.). Paris: Presses Univesitaires de France.

Romaine, S. (1984). On the problem of syntactic variation and pragmatic meaning in sociolinguistic theory. Folia Linguistica 18, 409-437.

Sankoff, D. (1988). Sociolinguistics and syntactic variation. I: Linguistics: The Cambridge Survey IV. Cambridge: Cambridge University Press, 140-161. Spang-Hanssen, E. (1963). Les prépositions incolores du français moderne. Copenhague: G. E. C. Gads Forlag.

Winford, D. (1996). The problem of syntactic variation. I: Sociolinguistic Variation: Data, Theory, and Analysis. Arnold, J., R. Blake, B. Davidson, S. Schwenter \& J. Solomon (red.). Stanford: CSLI Publications, 177-192.

\section{Øvrige kilder}

Le projet ELICOP: Étude LInguistique de la COmmunication Parlée. http:// bach.arts.kuleuven.be/elicop/

Trashtalk: http://trashtalk.co/2016/07/17/adam-silver-tu-pousses-lebouchon-je-ne-crois-pas-que-les-superteams-sont-bonnes-pour-la-nba/ 